\title{
The General Features and Distinguished Individuality of World-Class Universities
}

\author{
Huaxia Zhang \\ Jiangxi Institute of Fashion Technology, Nanchang 330102, China \\ 1071485582@qq.com
}

Keywords: world-class universities, general features, distinguished individuality, Chinese characteristics

\begin{abstract}
A few papers' discussion on general characteristics of world -class universities are being huge scale, long history, whole disciplines, excellent staff, university administering by professors, academic freedom, well-deserved reputation and ivory tower. However, there are huge difference through the comparison between China and other countries. It was recommended that not only induction being applied to study those general features, but also deduction being used to analyze those distinguished individuality, so as to find their essential marrow. It is necessary to learn advanced experience of international higher education, and to inherit and carry forward the essence of Chinese traditional culture, so as to do a good job in the university of socialism with Chinese characteristics.
\end{abstract}

\section{Introduction}

China' s recent quest to develop world-class universities is a significant phenomenon within the worldwide transformation of tertiary education[1]. Last year, the State Council issued a document that the whole scheme of how to promote the construction of world-class universities and world-class subjects, and many universities in our country has decided to achieve the goal of building world-class universities, which had been written into the thirteenth-five year plan. Besides, the status of some universities in our country increased gradually year after year and could complete with the famous foreign universities. All these make world-class universities become the hot topics of being attended and discussed for another time.

Although the concept of world-class universities existed for many years, there was not a clear definition and an accurate connotation of world-class universities. The general features, the main features, the main characters and evaluation system were concluded in some documents which admitted that the world-class universities had the same indicator system and evaluation criterion[2]. however, what they described in these documents were all preliminary conclusion with summary about world-class universities which need being researched forward. Through the search of CNKI ( China National Knowledge Infrastructure ), we could find that there are more than 200 papers about the topic of world-class universities since 2011.

\section{General features and exception}

\subsection{School Scale.}

In some documents, they thought that world-class universities had huge scale ( containing students number and buildings). They all firmly believed that huge universities construction were necessary for the $21^{\text {st }}$ century China economical and social development and were urgent[3].

At present, many universities in our country exceed one million, but most of them are not the first rate. Conversely, some world-class universities have not huge scale. From 2014 to 2015, California Institute of Technology only had 977 graduates students and 1204 undergraduates. The students in the école Normale Supérieure has only 2000, and only recruit 200 graduates every year.

At the late of $20^{\text {th }}$ and the beginning of $21^{\text {st }}$ century, in order to search for the theory gist for universities massive- enrollment, some documents criticized that the scale of some universities were 
small, leading bad teaching effects, they got the conclusion from Cole's huge universities. However, many documents in our country put the multiversity as huge university, its real meaning is diversification universities. The operation goal is diversification; the organization structure is diversification; the function instrument and management model are diversification. Cole himself had ever used luralistic university to express the same meaning of multiversity. To the road of building world-class universities, if we still indulged in expanding the scale, we could fall to attend to trifles and neglect the essentials.

\subsection{School History}

Some documents thought that long history was the main internal causes for world-class universities[4]. To speak frankly, some world-class universities really have long history, such as Oxford University, Cambridge University. However, other world-class universities have about one hundred years history, such as Standford University, California Institute of Technology, Chicago University, Carnegie Mellon University, University of California-Los Angeles and National University of Singapore. These universities inherit the reasonable tradition scientifically from classic universities, and rise sharply through the creation of pedagogy ideology[5].

Even the famous universities with a long history continue to today after a continuous evolution. Oxford University and Cambridge University all reform and create with the change of the social development. We have different criterion towards world-class universities in different time, and we should treat the problem of world-class universities construction dynamically[6]. The creation is the key for the success of world-class university. Some European Universities had put out of existence for many years due to not suitable to the time development.

Well, although Harvard University took some school regulations from Oxford University, Cambridge University and ancient institutions, they abandoned some malpractice from classic universities of UK. At the birth of Harvard, the university took different management model from UK universities, setting up school supervising committee and the directors board to operate the school together. At the beginning of $19^{\text {th }}$, Harvard University got rid of the teaching method of reciting and advocated the seminar-style instruction. At the late of $19^{\text {th }}$ and the beginning of $20^{\text {th }}$, Harvard University established the system of selective courses and credit and found graduate school to force science research. At the middle of $20^{\text {th }}$ century, Harvard University formulated the regulation that publish or punish for the staff.

Yale University is famous for the conservation, but that means it never changes. Yale University always sticks to its liberal education ideology, but corrects the connotation of the ideology. Although the 1828 Yale Report took the classic courses as the principal thing, the curricula system combined with major courses and common courses was chosen finally. At the same time, liberal education was not open to all students in Yale University, those students who would like to learn useful knowledge and science knowledge could be enrolled to Sheffield science school to study. In the 1870s, Yale and Harvard Universities had a drastic controversy on the advantage and disadvantage about promoting selecting course and opposed to select courses freely.

Paris university was built in 1794, and became a common university after the cancel of religionary courses at the beginning of $19^{\text {th }}$. Later, pure science research tradition was reformed to search for the balance between applied research and fundamental research. After the second world war, the tradition of emphasizing liberal arts and despising science was changed to achieve the balance between the liberal arts and science.

\subsection{Subject Setting}

some documents thought that world-class universities should have a lot of subjects. well, world-class universities really are the combination of science and technology, liberal arts and science and cross-disciplines. However, all subjects are contained in world-class universities are not possible and not necessary. Harvard University and Yale University are not far away in distance, and newly-built universities are hard to transcend other universities with a long history. Therefore, Harvard University and Yale University develops their preponderant disciplines and do not pursuit the subject number. Engineering school is vacant in Harvard University and medicine school \& education school are not established. Similarly, there are complements between Stanford University 
and University of California Berkeley. The former canceled architecture school and the later did not have whole medicine school, only owning eye school and public health school. As you know, there are no law school, medicine school and business school in Princeton University.

\subsection{Governance Model}

Some documents thought that real talents value the system guarantee in their scholar livings; only to ensure that they get support if they did well, no matter who assumed the control of the school[7]. Of course, some documents thought that there were too many administrators.

When the Medieval Universities were appearing at the beginning of $12^{\text {th }}$, the teachers were a guild and only carried out teaching functions. Especially the scale of school was small, there was no need to set up special management department. The school was really in control of the professors. However, with the development of higher education, the profession of school headmaster role is obvious and important, and professional management staff is appearing gradually.

At present, world-class universities all have enough full-time management and technology staff to support teaching and research, which could keep the professors to pay attention to scholar job and not being disturbed by the administrator and trifles. Well, after having the full-time administrator staff, the difference, the contradiction and the conflict produced between the scholars and the administrators. The tradition of all things being controlled by the professors were challenged. The management model are changing in universities. The professors in Harvard University complain that the school is completely in control of the president and administrators, and the professors themselves like the employees in enterprise. They have less consciousness as a master and maybe not loyal to the school as before.

In addition to that, there are several universities governance models, such as Continental, American, UK and Japan[8]. The right of presidents in different world-class universities has difference which lead to all kinds of governance models. All these add the complexity of learning from other universities.

\subsection{Scholar freedom}

Some documents thought that scholar freedom is the intern resource of world-class universities and put building world-class universities as the most important direction. In Fact, universities could not and had never obtained the whole freedom. The universities after Medieval were in control of religion, no teaching freedom, scholar ideas were confined; many universities had no research freedom.

\subsection{Ivory Tower}

Some documents thought that every world-class university is an ivory tower[9], hoping far away from the society and do what it wants to do and even go back to ivory tower. Under the university ideology of social service, a series of universities, standing for University of Wisconsin, were appearing, and they become the center and base of education, research, training, consulting and fruits promotion in locality. Harvard University and Yale University have been a long history in training gentlemen, and now they have broken away from the ivory tower. In 1846, the board of directors in Yale University set up professor enrollment for agriculture chemistry and psychology of animal and plant. Harvard University followed Cornell University steps which was built by the land donation to devote itself into the technology job that unqualified to take its place in higher circles[10]. During the second world war, Massachusetts Institute of Technology, California Institute of Technology and other universities assumed much task of national defense research, making great contribution for defeating fascist and promoting research strength and whole status. Stanford University promoted the birth of Silicon Valley and enhance its status.

The ideology of service society had become the lessons for many universities in different countries. Now, many universities are operated according to the need of the nation and the society. They cooperate and create, take out of ivory and surpass the ivory tower. 


\section{Summary}

World-class universities are appearing under the comparative research. The concept is obscure, and different researchers have different definitions towards it. Besides, different background will bring different research results. Just mention in above, the concept of world-class university is an dynamic concept, which changes according to the development of the society and the national policy. However, there is no doubt that world-class university plays an import role in any country. Just because the world-class university, our country is becoming more and more powerful; just because the world-class university, our living is becoming more and more comfortable; just because the world-class university, Chinese nation's great rejuvenation is coming near and near. Many countries are now creating world-class universities as essential parts of their higher education reform agendas, and as national goals [11]. Therefore, we must build world-class university and world-class subjects.

\section{References}

[1]. Li Jun. World-class Higher Education and the Emerging Chinese Model of the University[J]. PROSPECTS, 2012, Vol.42 (3), pp.319-339

[2]. Fang Yanming. On the Historical Thought and Practical Significance of creating top university[J]. Journal Nanjing University, human science and social science. 2000(2)

[3]. Li Jun. On the Thought of Building China Huge University[J]. Education Development Research. 1999(5).

[4]. Yan Yueqin. On the Formation of Top Universities[J]. Higher Education in Coal Industrial, 2003(1).

[5]. Bie Dunrong, Zhang Zheng. Education Ideology and the Formation of world-class university[J]. Higher Education Research, 2010(7).

[6]. Wang Zhanjun, Goal and Method: Construction of World-class University and Research University[J]. Tsinhua Journa of Education, 2003(3).

[7]. Zhu Qingshi. Some Problems that Need Being Valued in building Top University[J]. Tsinhua Journa of Education, 2003(6).

[8]. Zhong Binlin, Zhou Haitao, Comparative Research of World-class President Management[J]. Journal of National Academy of Education Administration, 2012(2) .

[9]. Liu Daoyu. On the Function Position of World-class University[J]. Higher Education Exploration, 2010(1).

[10]. Clark Cole, the Function of University[M]. Nanchang, Jiangxi Education Publishing House: 34-35.

[11]. Jeongwoo Lee. Creating World-class Universities: Implications for Developing Countries. PROSPECTS, 2013, Vol.43 (2), pp.233-249. 